ZOOLOGIA 29 (3): 219-226, June, 2012

doi: $10.1590 /$ S1984-46702012000300005

\title{
Comparative studies on the histology and ultrastructure of the siphons of two species of Tellinidae (Mollusca: Bivalvia) from Brazil
}

\author{
João E.V.V. Vitonis' ${ }^{1}$ Cristiane P. Zaniratto', Fabrizio M. Machado² \& Flávio D. Passos ${ }^{1,3}$ \\ 1 Departamento de Biologia Animal, Instituto de Biologia, Universidade Estadual de Campinas. Caixa Postal 6109, \\ 13083-970 Campinas, SP, Brazil. \\ 2 Programa de Pós-Graduação em Ecologia, Instituto de Biologia, Universidade Estadual de Campinas. \\ 13083-970 Campinas, SP, Brazil. \\ ${ }^{3}$ Corresponding author. Email: flaviodp@unicamp.br
}

\begin{abstract}
Despite the great importance of the siphons for infaunal bivalves, only a few studies have examined their tissues using histology techniques or scanning electron microscopy. In the present study, the siphons of Tellina lineata Turton, 1819 and Macoma biota Arruda \& Domaneschi, 2005 were investigated. The siphon walls are composed by a series of muscle sheets of longitudinal (" $\mathrm{L}$ "), circular (" $\mathrm{C}$ ") and radial (" $\mathrm{R}$ ") fibers, with a clear pattern common to both species: there is a main median longitudinal layer ( $\mathrm{Lm}$ ), and two peripheral circular layers, one inner (Ci) and one outer (Co), near the epithelia. A median circular layer ( $\mathrm{Cm}$ ) separates an internal (Lmi) from an outer (Lmo) median longitudinal layer. Further, the Co is split by a thin outer longitudinal layer (Lo), forming Coi and Coo layers, the former being obliquely oriented. Thin radial fibers (R) delimit clear packages of Lmi and Lmo fibers. In each siphon, there are six longitudinal nerve cords, running within the Lmi layer, adjacent to the $\mathrm{Cm}$. The inhalant and exhalant siphons of $M$. biota are very similar in structure, but the Lmo of the exhalant siphon is almost twice as thick as its Lmi, while in the inhalant siphon these layers have similar thicknesses; the Coi is very thick, especially in the exhalant siphon. The inhalant siphon of $T$. lineata is very similar to that of M. biota, differing only with respect to the thickness of the Coi, which in the former species is not as well developed as in the latter. The Lmo of the exhalant siphon of $T$. lineata is by far the most developed layer, with the Lmi represented only by uniseriate small cells; in the vicinities of the nerve cords, the $\mathrm{Cm}$ is split in two layers. The epithelia of both siphons of $M$. biota and $T$. lineata bear ciliated receptors, which were difficult to observe as they were frequently covered with mucus. It was possible to observe that cilia are present in both species, differing in length and in the number per receptor between the inhalant and exhalant siphons, and between the species. Detailed comparisons among the siphons of $M$. biota and $T$. lineata and other bivalve species are very difficult, because of at least two reasons. First, each investigator has used different methods to prepare and observe the siphons through histological sections; and second, different nomenclatural schemes are used to describe the musculature of the siphons, causing confusion when the same layers are compared among different species. In order to unify the nomenclature of tissue layers of the bivalve siphons, we now propose a scheme to name these layers based on topological homology.
\end{abstract}

KEY WORDS. Ciliated receptors; histology; musculature; Tellinoidea.

\begin{abstract}
Siphons are very important structures for infaunal bivalves, allowing these animals to maintain contact with the water above the substrate, even when their bodies are buried, and to continue to capture food, exchange gas, and dispose of non-ingested particles (pseudofeces), feces, excreta and gametes. For many species, siphons also function as sensory organs, mainly photoand mechanoreceptors (FISHELSON 2000). The two siphons (inhalant and exhalant) are formed by the fusion of the mantle margins, and may be separated from each other, or partly to completely fused. Muscle fibers composing their walls provide various types of movements, such as retraction within the confines of the shell, or protraction to expose the siphon and con-
\end{abstract}

tact the water column. The siphons are characteristic of different groups of bivalves, and are closely related to their evolutionary success in the colonization of soft substrates in various types of coastal environments, such as sandy beaches, estuaries and the sublittoral zone (STANLey 1968). The siphons allow the animals to live more deeply within the sediment, where environmental conditions are less variable than at the surface, and where they are more protected against predators (STANLEY 1975).

Comparing the siphons of several taxa of bivalves, Yonge $(1948,1957)$ classified them into four basic types, determined by the degree of fusion of the marginal folds of the mantle lobes. The members of the superfamily Tellinoidea Blainville, 1814, 
for example, were classified as bearing type-A siphons, which are formed by the fusion of the internal folds only (YongE 1948, 1949). Yonge (1949) also studied details of the muscle layers present in the siphons of Tellinoidea, and noted that they are arranged in a clear pattern. Other investigators also compared the siphons of various species of bivalves; Amouroux (1980) examined the relationships between the macroscopic structure (length, presence/absence of tentacles in the opening) and the function of these organs, according to the specific habitat of the species. Duval (1963) studied the organization of the muscle layers, nerve cords and hemocoel from several species of bivalves, including some members of Tellinoidea. More recently, SARTORI et al. (2008), studying the Veneridae of Thailand, examined the morphology of the siphons of 15 species of this family.

When protruded and exposed in the water, siphons can be a food item for fish, crabs and seabirds (Salas et al. 2001). Therefore, many species of bivalves have a great capacity to regenerate the siphon, an important adaptation to its frequent loss (Hodgson 1982, Luzzato \& Penchaszadeh 2001). Still, in many species the siphon is the only region of the body in direct contact with the water above the substrate, and because of that, it bears a large concentration of sensory organs, especially ciliated receptors. Several groups of molluscs have such structures on the body surface, and their ultrastructure has been described in several studies, including some on shellfish (Hodgson et al.1982, 1983, Hodgson \& Fielden 1984, Pekkarinen 1984, 1986, Ansell et al. 1999, Fishelson 2000).

Among the groups of Bivalvia that have siphons, members of Tellinoidea, and in particular those of Tellinidae Blainville, 1814 are among the most important in tropical and temperate waters, both ecologically and in number of species. The siphons of the Tellinoidea always number two, non-fused, a ventral inhalant and a dorsal exhalant; in Tellinidae they are very long and highly mobile. Yonge (1949), based on a comparative study of the siphons, organs and structures of the pallial complex, and aspects of the behavior of several species in their habitats, suggested that all tellinoideans are deposit feeders. This view was criticized by Holme (1961) and PoHLo (1969), who demonstrated that not all tellinoideans have this habit; instead, many species have now been proved to be suspension feeders (e.g., Pohlo 1969, Passos \& Domaneschi 2004). For investigation of the mode of life and feeding habits of members of this superfamily, other organs may also be examined, for example the labial palps and ctenidia. However, the structure and behavior of the siphon continue to be important characters used to infer the type of habit of these animals.

In the present study, the siphons of two Brazilian species of Tellinidae, Tellina lineata Turton, 1819 and Macoma biota Arruda \& Domaneschi, 2005 were investigated. The former has a wide geographical distribution, being recorded from the USA, West Indies, Venezuela and Brazil (Rios 1994, 2009). Macoma biota was recently described by ArRuda \& Domaneschi (2005), based on specimens found in the intertidal zone at Praia da
Cidade, Caraguatatuba city, state of São Paulo. Apart from their shell characteristics and their geographical and bathymetric distribution (Rios 1994, 2009, ARRUda \& DomanesChi 2005, AMARaL et al. 2006), and aspects of their ecology (ARRUda \& AMAral 2003, ARRUDA et al. 2003), little information is available on these species, in particular details of the anatomy of their siphons. ARRUDA et al. (2003) and Piffer et al. (2011) described the behavior and morphology of the siphons of T. lineata and M. biota, respectively, but provided no details on the anatomy and the ultrastructure. We investigated histological aspects of these organs of both species, aiming to describe the internal organization of their tissues, including the muscle layers and nerve cords. The siphons were also observed under scanning electron microscopy, aiming to record the structure and distribution of the ciliated receptors found on the inner and outer epithelia.

\section{MATERIAL AND METHODS}

Specimens of T. lineata and M. biota were obtained from Praia da Cidade, Caraguatatuba, state of São Paulo, on the Brazilian southeastern coast. Individuals of T. lineata were collected in January and February 2009, and March, April and May 2010, and those of M. biota in February and September 2009, and May and June 2010. The identification was based on shell characters, comparing with descriptions and illustrations of these species provided by Arruda \& Domaneschi (2005) and Amaral et al. (2006). Voucher specimens were deposited in the mollusc collection of the Museu de Zoologia "Prof. Dr. Adão José Cardoso", UNICAMP: lots ZUEC-BIV 1860, 1971, 3211, 3212 and 3216 of T. lineata; and lots ZUEC-BIV 1853, 1965, 1966, 3213, 3214 and 3215 of M. biota.

The siphons were removed from living animals, taking care not to damage them and avoiding the excess of mucus and fine sand that frequently adhere to their epithelia. A solution of $2 \%$ paraformaldehyde and $2.4 \%$ glutaraldehyde, with $2.5 \mathrm{mM}$ sodium chlorate and $0.58 \mathrm{M}$ sucrose, buffered with 0.1 $\mathrm{M}$ sodium cacodylate, $\mathrm{pH} 7.4$ adjusted with $0.2 \mathrm{~N} \mathrm{HCl}$, was used to fix the material used for both the light and scanning electron microscope (SEM) analyses. After one day in this fixative solution, the material was transferred to $0.1 \mathrm{M}$ sodium cacodylate buffer.

For histological sections, the material was washed in the same buffer and dehydrated in an ascending ethanol series (70\%, 80\%, 95\% and three successive passages in 99\%, with 20 minutes in each bath) prior to embedding in glycolmethacrylate resin $\left(\right.$ Historesin $^{\circledR}$ ). Cross and longitudinal 3- $\mu \mathrm{m}$ sections were stained with Delafield's hematoxylin and counterstained with eosin. These were analyzed with the aid of a Zeiss optical microscope fitted with a drawing tube, which was used to draw the more representative histological sections.

For the SEM analysis, the samples were washed in the same buffer and were then fixed a second time in $1 \%$ osmium tetroxide solution for two hours. The siphons of M. biota showed 
a large amount of mucus on their epithelia; in order to eliminate it, they were placed in a bath of $1 \% \mathrm{HCl}$ for five minutes, following Hodgson \& Fielden (1984) and Ansell et al. (1999). The excess osmium was washed in three baths of buffer, and then the material was dehydrated in an ethanol series (30\%, $50 \%, 70 \%, 90 \%$ for 20 minutes and three times in $100 \%$ for 10 minutes), critical point dried, covered with gold, and analyzed by means of a Jeol SM-5800LV Scanning Electron Microscope.

\section{RESULTS}

\section{Histology}

The walls of the siphons of M. biota and T. lineata are composed of a series of muscle layers, which are confined within the outer (Eo) and inner unistratified epithelia (Ei), the latter facing the lumen. Epithelial cells are cubic or columnar, bearing many microvilli and a well-developed nucleus and nucleolus. The fibers of the muscle layers are oriented in three basic ways: longitudinally, attached to the shell valves and extending up to the distal tip of the siphons; arranged as rings that alternate with the longitudinal musculature; and radially, attached to both epithelia. Here, these layers are termed "L" (longitudinal), "C" (circular) and "R" (radial), respectively.
There is a clear pattern of distribution of these layers in the siphon walls of both species, with a main longitudinal layer positioned in the median portion (Lm), and two peripheral circular layers, one inner (Ci) and one outer (Co), near their respective epithelia. The $\mathrm{Lm}$ is always the most developed layer, and is divided by a median circular layer $(\mathrm{Cm})$ which separates an inner (Lmi) from an outer (Lmo) median longitudinal layer (Figs 1-8). Between the $\mathrm{Cm}$ and Lmo are hemocoel spaces. The $\mathrm{Ci}$ is very thin, one cell thick, while the Co is divided by a thin outer longitudinal layer (Lo), forming Coi and Coo layers, the latter lying below the outer epithelium. Examination of cross and longitudinal histological sections revealed that Lo and Coo are uniseriate layers, while the Coi is thick and its fibers are oriented obliquely to the other layers. The narrow radial fibers (R) are not entirely visible from one epithelium to another, except within the middle longitudinal layers where they delimit clear packages of Lmi and Lmo fibers, also compartmentalizing the hemocoels. Near the innermost fibers of the $\mathrm{Ci}$ and Coi, the radial muscles are branched. In each siphon of both species there are six evenly distributed longitudinal nerve cords $(\mathrm{N})$, which run within the Lmi, adjacent to the $\mathrm{Cm}$. This general pattern of the characteristics and distribution of the epithelial, muscle and nerve tissues may be modified in the

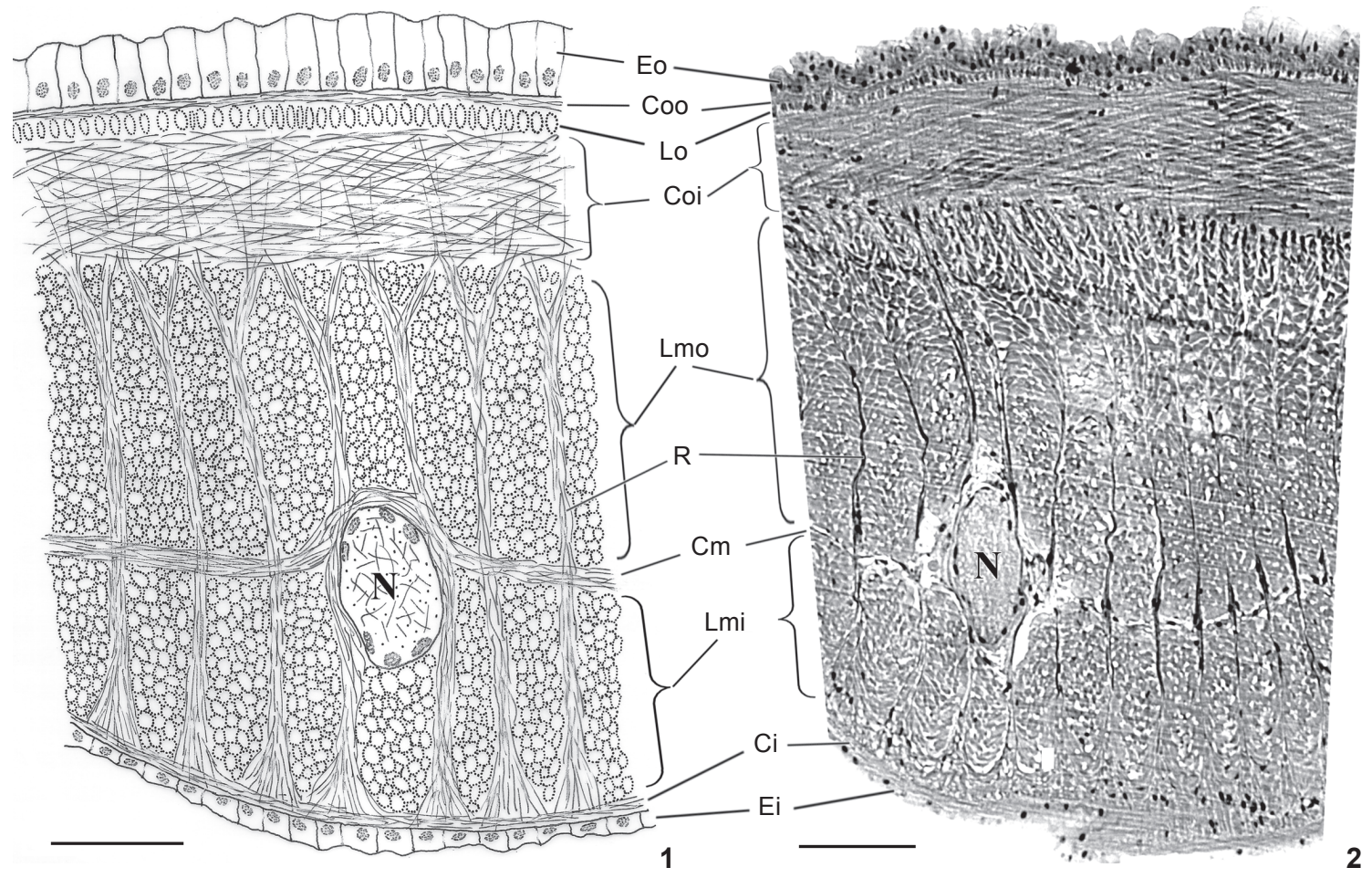

Figures 1-2. Macoma biota. Diagrammatic representation (1) of the cross section (2) of the inhalant siphon. (Ci) Inner circular layer, (Cm) median circular layer, (Coi and Coo) inner and outer parts of the outer circular layer, (Ei) inner epithelium, (Eo) outer epithelium, (Lmi and Lmo) inner and outer parts of the median longitudinal layer, (Lo) outer longitudinal layer, (N) nerve cord, (R) radial fibers. Scale bars: $10 \mu \mathrm{m}$. 
species examined, and in the inhalant and exhalant siphons of the same species.

The inhalant and exhalant siphons of M. biota are very similar in structure. The wall of the inhalant siphon is relatively thick, about $60 \mu \mathrm{m}$, whereas the wall of the exhalant siphon measure $40 \mu \mathrm{m}$ when examined by histological sections (Figs 1-4). The median longitudinal layers are very well developed, with Lmi and Lmo almost equal in thickness in the inhalant siphon; in the exhalant the Lmo is the more developed layer, almost twice the thickness of the Lmi. The Coi is also very thick, especially in the exhalant siphon. The nerve cords are large, causing a local dislodgement of the $\mathrm{Cm}$ and reduction of the thickness of the Lmi and Lmo. Characteristically tall epithelial cells are present in the exhalant, while in the inhalant they are slightly different among the internal and external epithelia, being almost twice as tall in the former than in the latter.

The inhalant siphons of $T$. lineata and $M$. biota have very similar internal structures, differing only in the thickness of the Coi, which in the former species is less developed than in the latter (Figs 5 and 6). Their exhalant siphons, on the contrary, are slightly different, with the siphon of $T$. lineata having a thin wall. Here, the Lmo is by far the most developed layer, with wide fibers near the $\mathrm{Cm}$ and narrow near the Coi; the Lmi is represented only by small uniseriate cells, except in the vicinities of the nerve cords, where the $\mathrm{Cm}$ is divided in two layers, with fibers of the Lmi also present on both sides of the nerves. In both the inhalant and exhalant siphons of T. lineata, near the Coi and accompanying the radial muscles, there are structures heavily stained with hematoxylin; these are radial nerve endings (TN), branching toward the outer epithelium, as described by PeKKaRinen (1986).

\section{Scanning Electron Microscopy}

The epithelia of both siphons of M. biota and T. lineata bear ciliated receptors that are very difficult to observe because they are frequently covered with mucus, particularly on the outer epithelium. The $\mathrm{HCl}$ solution was more or less effective in removing it, but the ciliated receptors were in a poor state of preservation in most electron micrographs. It was possible to observe that cilia are present in both species, differing in length and in the number per receptor, between the inhalant and exhalant siphons and between the species.

In the outer epithelia of both siphons of M. biota, there are rounded elevations $15 \mu \mathrm{m}$ in diameter, bearing about 12 cilia at their tips, each $3 \mu \mathrm{m}$ in length (Fig. 9). The aperture of the inhalant siphon has tentacles in the shape of small projections, bearing on their inner surface a considerable number of ciliated receptors $\left(10 / 100 \mu \mathrm{m}^{2}\right)$, consisting of a cluster $(>15)$ of cilia 4-5 $\mu \mathrm{m}$ in length. These receptors are also present on the epithelium facing the lumen of this siphon, although sparser (about 20/10000 $\mathrm{mm}^{2}$ ) and having more than 22 longer cilia (4-7 $\mu \mathrm{m}$ long) (Fig. 10). The exhalant siphon does not have tentacles at the tip, but similar receptors to that of the inhal-

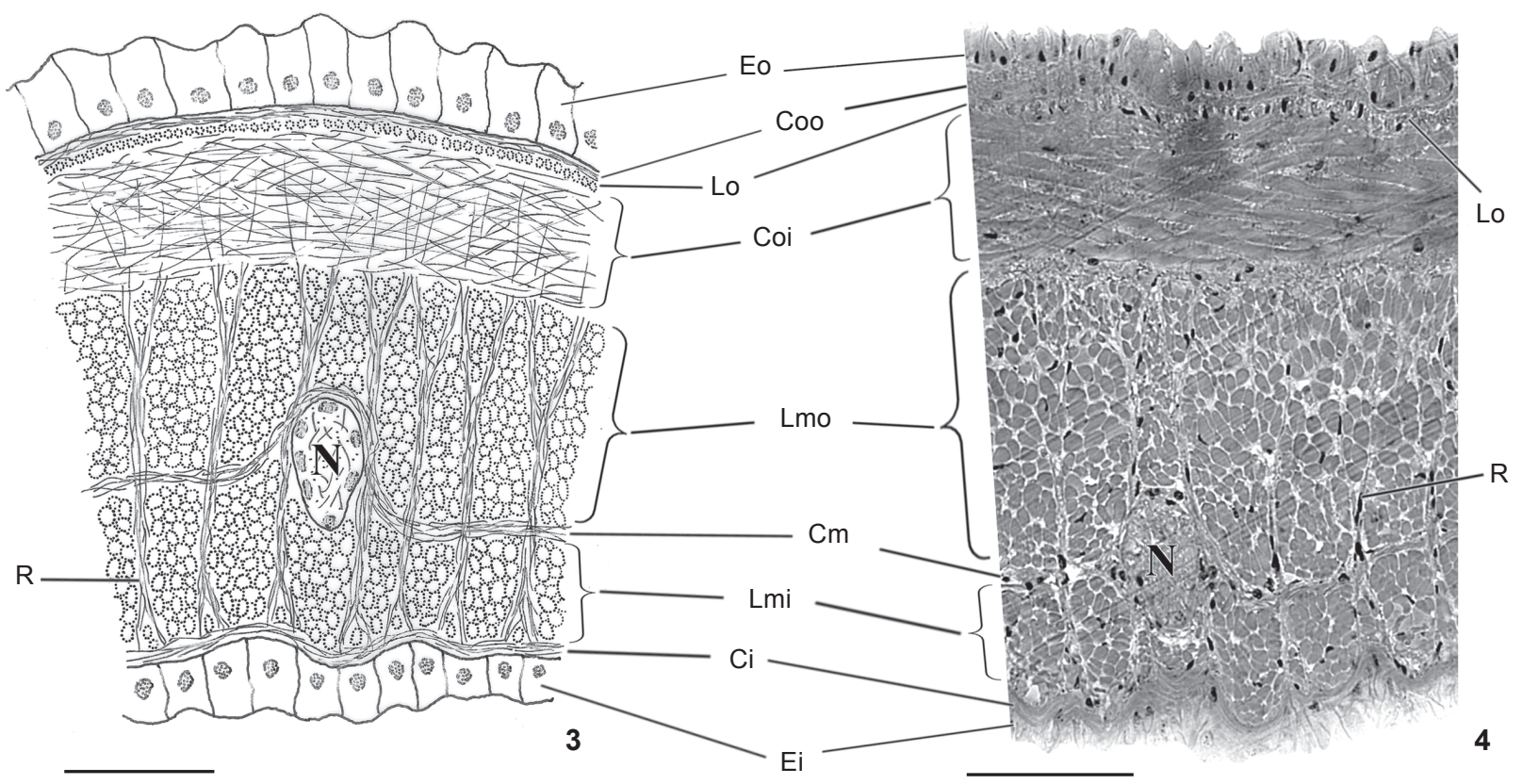

Figures 3-4. Macoma biota. Diagrammatic representation (3) of the cross section (4) of the exhalant siphon. (Ci) Inner circular layer, (Cm) median circular layer, (Coi and Coo) inner and outer parts of the outer circular layer, (Ei) inner epithelium, (Eo) outer epithelium, (Lmi and Lmo) inner and outer parts of the median longitudinal layer, (Lo) outer longitudinal layer, (N) nerve cord, (R) radial fibers. Scale bars: $10 \mu \mathrm{m}$. 


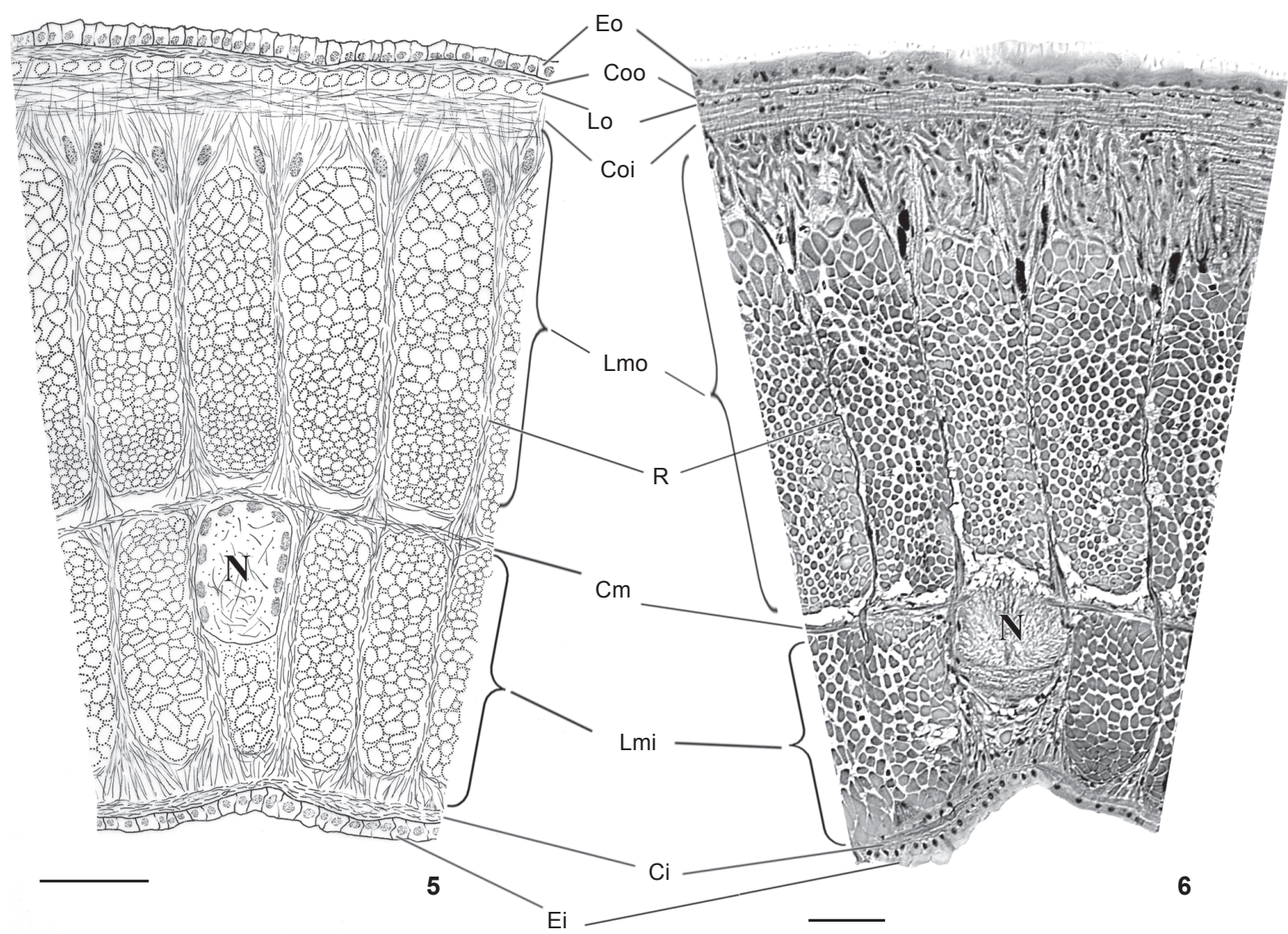

Figures 5-6. Tellina lineata. Diagrammatic representation (5) of the cross section (6) of the inhalant siphon. (Ci) Inner circular layer, (Cm) median circular layer, (Coi and Coo) inner and outer parts of the outer circular layer, (Ei) inner epithelium, (Eo) outer epithelium, (Lmi and Lmo) inner and outer parts of the median longitudinal layer, (Lo) outer longitudinal layer, (N) nerve cord, (R) radial fibers. Scale bars: $10 \mu \mathrm{m}$.

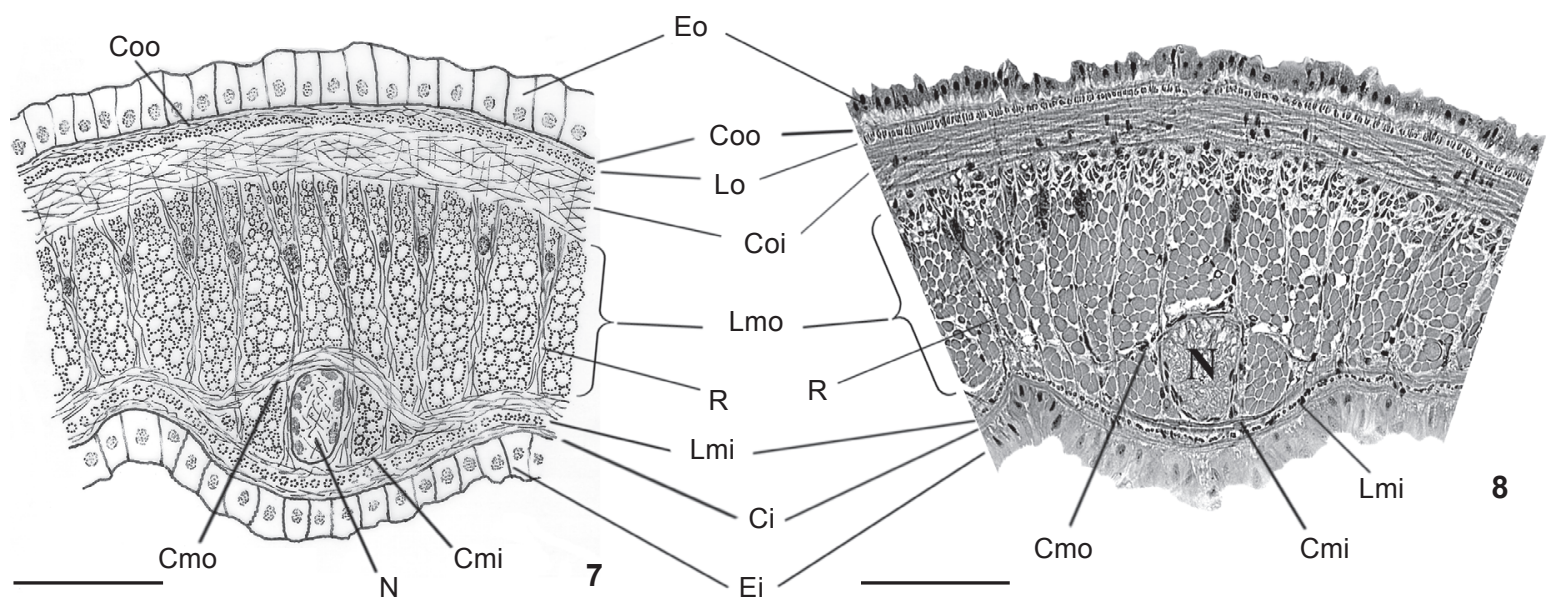

Figures 7-8. Tellina lineata. Diagrammatic representation (7) of the cross section (8) of the exhalant siphon. (Ci) Inner circular layer, (Cmi and $\mathrm{Cmo}$ ) inner and outer parts of the median circular layer, (Coi and Coo) inner and outer parts of the outer circular layer, (Ei) inner epithelium, (Eo) outer epithelium, (Lmi and Lmo) inner and outer parts of the median longitudinal layer, (Lo) outer longitudinal layer, (N) nerve cord, $(\mathrm{R})$ radial fibers. Scale bars: $10 \mu \mathrm{m}$. 

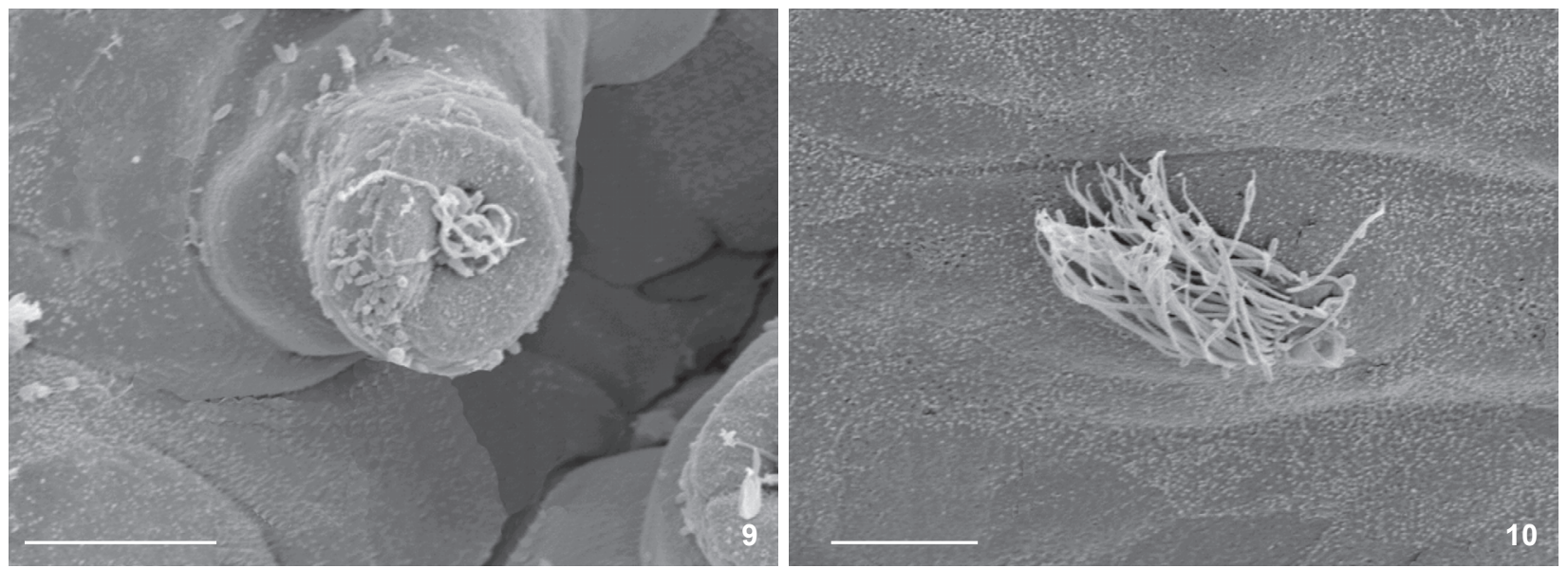

Figures 9-10. Macoma biota. Scanning electron micrographs of the cilia types: (9) tuft of short cilia at the tip of a rounded elevation on the outer epithelium of the exhalant siphon; (10) tuft of long cilia on the lumen epithelium of the inhalant siphon. Scale bars: $10 \mu \mathrm{m}$.

ant are present, with 15-20 cilia 3-5 $\mu \mathrm{m}$ in length. Apart from these cilia, there are other receptors which have longer cilia (about $15 \mu \mathrm{m}$ in length); they are also distributed on the epithelium facing the lumen, and here are even longer $(20-30 \mu \mathrm{m}$ long) and numerous (>30).

The outer epithelium of both siphons of T. lineata has the same receptors, with shorter cilia than in M. biota, but on the inner epithelium two other types of receptors were also found. On the inhalant siphon is a less common type, with about ten longer $(10 \mu \mathrm{m})$ cilia (Fig. 11); and another, even rarer type with more than ten small $(1 \mu \mathrm{m})$ cilia (Fig. 12). On the exhalant siphon, as in M. biota, there is one most abundant type with many cilia ( $>20), 10-14 \mu \mathrm{m}$ long (Fig. 13).

\section{DISCUSSION}

Both species have long, highly mobile siphons, similar to those of other members of Tellinidae (Yonge 1949, Levinton 1991, Zwarts et al. 1994, Domaneschi 1995). In general, the length of the siphons is correlated with the depth to which each bivalve species can burrow; the longer the siphon, the deeper the animal can dig. M. biota and T. lineata are deep-burrowing species, with very long siphons. ARruda et al. (2003) recorded that $T$. lineata is able to burrow to a depth of $8 \mathrm{~cm}$, with its siphons showing intense activity, particularly the inhalant one, which is placed close to and with the opening resting on the substratum, and moves in small arcs or even $360^{\circ}$; it has been suggested that this behavior is related to a deposit-feeding habit. Macoma biota burrows approximately 20 to $40 \mathrm{~cm}$ below the surface, with its siphons lying passively on the substratum, or extended in the water column, sporadically moving more actively, for either deposit- or suspension-feeding (PIFfer et al. 2011).

The organization of muscle layers, nerve cords and the hemocoels within the walls of the siphons of the Tellinoidea follows a clear pattern, as earlier described by Yonge (1949) and Duval (1963) for several species. This pattern is characterized mainly by the presence of different muscle layers, seven in total: three longitudinal and four circular. Further, radial fibers compartmentalize the median longitudinal layers, where there are also hemocoels and six well-developed longitudinal nerve cords running throughout the length of the siphon. The siphons of M. biota and T. lineata show this same pattern, with the median longitudinal layer as the most evident. Yonge (1949) linked the circular layers to the constriction of the siphons, while linking longitudinal muscles with retraction. The arrangement of the longitudinal muscles in several packages, separated by radial muscles, may improve control of the mobility of the siphons.

Although the siphons of the species examined here are similar in structure to those of other bivalves, detailed comparisons among the characteristics of their muscle layers are difficult to make, because of at least two reasons. First, each author used different methods to prepare and observe the siphons through histological sections. So, observation of thin layers of musculature, which are currently difficult to distinguish (as noted by PEKKARINen 1986), can be neglected when they are badly fixed. Similarly, microvillosities were noted by Pekrarinen (1986) and were also present in M. biota and T. lineata; they may be present in other Tellinidae, although not mentioned by Yonge (1949) and Duval (1963). Second, different investigators use different methods to describe the musculature of the siphons, causing confusion when the same layers are compared among different species, even within the same bivalve genus or family. A clear problem arises, for example, when the layers are numbered from the outer to the inner epithelium (e.g., Domaneschi 1995), or from the inner to the outer (e.g., YongE 1949). Therefore, we avoided numbering the tissue layers, and we now propose a method to describe them based on topological homology. All 


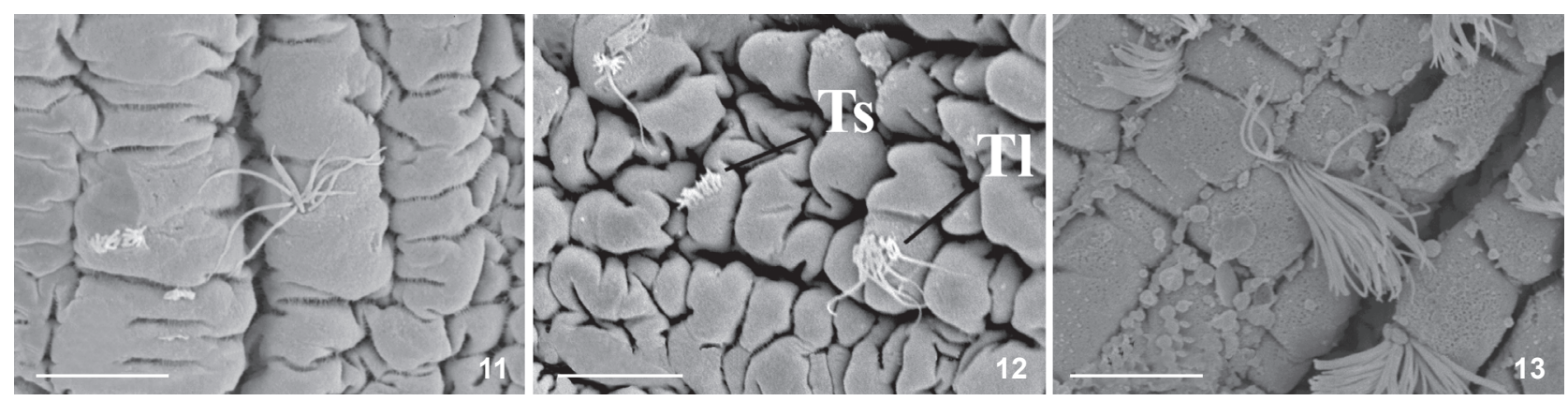

Figures 11-13. Tellina lineata. Scanning electron microscopy of the cilia types: (11) tuft of few long cilia on the inner epithelium of the inhalant siphon; (12) tufts of short and long cilia of the inhalant siphon; (13) Tuft of long cilia of the exhalant siphon. (TI) Tuft of long cilia, (Ts) tuft of short cilia. Scale bars: $10 \mu \mathrm{m}$.

the species studied have a clear median longitudinal layer, here termed "Lm"; peripheral to it are layers of circular and longitudinal muscles, termed "Co" or "Ci", and "Lo" or "Li", according to their proximity to the outer or inner epithelia. Similarly, further subdivisions can be also incorporated, such as layers termed "Lmo" and "Lmi", consisting of a median circular $(\mathrm{Cm})$ present within the Lm. More than a simply nomenclature standardization, with this proposal, hypotheses of homology between the muscle layers of different species will be put clearly by other researchers in the literature. Then, these cases of topological homology will be tested through future studies on ontogeny or by phylogenetic analyses.

The SEM analysis revealed that $T$. lineata and M. biota have a main type of ciliated receptor, composed by a tuft of about 15 short $(4-5 \mu \mathrm{m})$ cilia. This type of receptor has also been observed in other species of Tellinoidea, e.g., Donax serra Röding, 1798 and Donax sordidus Hanley, 1845, in which Hodgson \& Fielden (1984) termed this structure "type I"; and Macoma balthica (Linnaeus, 1758), where it was termed "Hill organs" by PeKKarinen (1986). This is the most abundant ciliated receptor on both epithelia of the siphons of the species examined here, as also described for Donax vittatus (Da Costa, 1778) by Ansell et al. (1999). However, M. biota and T. lineata have two additional types of ciliated receptors. The first type was not found in M. biota, although this result must be interpreted with caution, as the siphons of this species are large and accumulate especially large amounts of mucus, impeding detailed observations through their entire length. This cilia type, found in T. lineata, is very similar to type II of Hodgson \& FieLden (1984). The second type, with many, very large cilia, was found abundantly on the inner side of the exhalant siphon. Based on the size of these cilia, it would be better to classify this second type as type III of Hodgson \& Fielden (1984); although the structures observed in this study appear to have more cilia than reported by these authors.

In $M$. biota, some ciliated receptors are very similar to the "Goblet organs" of M. balthica (PeKKaRInen 1984, 1986). These structures consist of a rounded elevation with cilia in a depres- sion on the tip. According to PeKKARINen $(1984,1986)$, the receptors are arranged in rows, following the course of the main nerve cords. In the present study, it was not possible to observe these rows, although such structures have only been located in the outer epithelium. FisHelson (2000) suggested that these structures may somehow be related to the type III ciliated receptor. Such structures were not observed in T. lineata, which, however, has papillae on the outer epithelium. These papillae may be "Goblet organs" with cilia that are fully retracted, or alternatively may not be homologous to goblet organs; however, the present data do not allow a conclusion about this matter.

The functions of the three types of receptors in bivalves are still much debated. Hodgson \& Fielden (1984) suggested that they function primarily as mechano- and chemoreceptors, and Pekrarinen (1986) related them to the lateral line system of fishes. Even their classification into only three types and the criteria used have been questioned; FisHeLSON (2000) restricted the types to, basically, the size of the cilia present on the organs: $<3 \mu \mathrm{m}$ type I, 5 to $7 \mu \mathrm{m}$ type II, and 12-19 $\mu \mathrm{m}$ type III. The data from this study indicate that such a classification is inadequate to describe all the variations of the different types of receptors of $M$. biota and T. lineata, even those that are present in the same species.

The results obtained so far allow us to glimpse that the study of structure and organization of the siphon tissues could add more data for more detailed knowledge of the biology of these species. This information will inform discussions of the homology of the structures, in studies on the phylogeny of these bivalves.

\section{ACKNOWLEDGMENTS}

This work was supported by a scholarship awarded by FAPESP to the first and second authors (Proc. 2009/07440-0 and 2009/08144-6, respectively); logistical support provided by CEBIMar; and the assistance of Gisele Introíni, Shirlei ReccoPimentel, and Antônia Cecília Z. Amaral and the Laboratório de Microscopia of the IB-UNICAMP. 


\section{LITERATURE CITED}

Amaral, A.C.Z.; A.E. Rizzo \& E.P. ARruda. 2006. Manual de Identificação dos Invertebrados Marinhos da Região Sudeste-sul do Brasil. São Paulo, Editora USP, vol. 1, 287p.

Amouroux, J.M. 1980. Etude monographique des siphons de quelques mollusques bivalves: adaptation et morphologie. Oceanis 5 (1): 33-89.

Ansell A. D.; R. Harvey \& C.P. Günther. 1999. Recovery from siphon damage in Donax vittatus (Da Costa) (Bivalvia: Donacidae). Journal of Molluscan Studies 65: 223-232.

Arruda, E.P. \& A.C.Z. Amaral. 2003. Spatial distribution of mollusks in the intertidal zone of sheltered beaches in southeastern of Brazil. Revista Brasileira de Zoologia 20 (2): 291300.

ARruda, E.P. \& O. DOMANesCHI. 2005. New species of Macoma (Bivalvia: Tellinoidea: Tellinidae) from southeastern Brazil, and with description of its gross anatomy. Zootaxa 1012: 13-22.

Arruda, E.P.; O. Domaneschi \& A.C.Z. Amaral. 2003. Mollusc feeding guilds on sandy beaches in São Paulo State, Brazil. Marine Biology 143: 691-701.

Domaneschi, O. 1995. A Comparative Study of the Functional Morphology of Semele purpurascens (Gmelin, 1791) and Semele proficua (Pulteney, 1799) (Bivalvia: Semelidae). The Veliger 38 (4): 323-342.

Duval, D.M. 1963. The comparative anatomy of some Lamellibranch siphons. Proceedings of the Malacological Society of London 35: 289-295.

Fishelson, L. 2000. Comparative morphology and cytology of siphons and siphonal sensory organs in selected bivalve molluscs. Marine Biology 137: 497-509.

Hodgson, A.N. 1982. Studies on wound healing and regeneration of the siphons of the bivalve Donax serra (Rüoing). Transactions of the Royal Society of South Africa 44 (4): 489-499.

Hodgson, A.N. \& L.J. Fielden. 1984. The structure and distribution of peripheral ciliated receptors in the bivalve molluscs Donax serra and D. sordidus. Journal of Molluscan Studies 50: 104-112.

Hodgson, A.N.; L.J. Fielden \& R.H.M. Cross. 1982. The structure and distribution of peripheral ciliated receptor cells in bivalve molluscs. Electron Microscopy Society of Southern Africa - Proceedings 12: 79-80.

Hodgson, A.N.; R.H.M. Cross \& L.J. Fielden. 1983. The structure and distribution of stacked plates in the siphon wall of Donax sordidus and Solen capensis (Mollusca: Bivalvia). Micron 14: 141-145.

Holme, N.A. 1961. Notes on the mode of life of the Tellinidae (Lamellibranchia). Journal of the Marine Biological Association of the United Kingdom 41: 699-703.

Levinton, J.S. 1991. Variable feeding behavior in three species of Macoma (Bivalvia: Tellinacea) as a response to water flow and sediment transport. Marine Biology 110: 375-383.

Luzzato, D.C. \& P.E. Penchaszadeh. 2001. Regeneration of the inhalant siphon of Donax hanleyanus (Philippi, 1847)
(Bivalvia, Donacidae) from Argentina. Journal of Shellfish Research 20 (1): 149-153.

Passos, F.D. \& O. Domaneschi. 2004. Biologia e anatomia funcional de Donax gemmula Morrison (Bivalvia, Donacidae) do litoral de São Paulo, Brasil. Revista Brasileira de Zoologia 21 (4): 1017-1032.

Pekrarinen, M. 1984. Regeneration of the inhalant siphon and siphonal sense organs of brackish-water (Baltic Sea) Macoma balthica (Lamellibranchiata, Tellinacea). Annales Zoologici Fennici 21: 29-40.

PekKarinen, M. 1986. Histology of the siphons of Macoma balthica (Bivalvia: Tellinidae). Annales Zoologici Fennici 23: 77-95.

Piffer, P.R.; E.P. Arruda \& F.D. Passos. 2011. The biology and functional morphology of Macoma biota (Bivalvia: Tellinidae: Macominae). Zoologia 28 (3): 321-333.

Pohlo, R. 1969. Confusion concerning deposit feeding in the Tellinacea. Proceedings of the Malacological Society of London 38: 361-364.

Rios, E.C. 1994. Seashells of Brazil. Rio Grande, Museu Oceanográfico Prof. E.C. Rios, Fundação Universidade do Rio Grande, $2^{\text {nd }}$ ed., 368p.

Rios, E.C. 2009. Compendium of Brazilian Sea Shells. Rio Grande, Evangraf, 668p.

Salas, C.; C. Tirado \& M.E. Manjón-Cabeza. 2001. Sublethal footpredation on Donacidae (Mollusca: Bivalvia). Journal of Sea Research 46: 43-56.

Sartori, A.F.; C. Printrakoon; P.M. Mikkelsen \& R. Bieler. 2008. Siphonal Structure in the Veneridae (Bivalvia: Heterodonta) with an assessment of its Phylogenetic Application and a Review of Venerids of the Gulf of Thailand. The Raffles Bulletin of Zoology (Suppl. 18): 103-125

Stanley, S.M. 1968. Post-Paleozoic adaptive radiation of infaunal bivalve molluscs - a consequence of mantle fusion and siphon formation. Journal of Paleontology 42 (1): 214-229

Stanley, S.M. 1975. Adaptive themes in the Evolution of the Bivalvia (Mollusca). Annual Review of Earth and Planetary Sciences 3: 361-385.

YoNGE, C.M. 1948. Formation of siphons in Lamellibranchia. Nature 161: 198-199.

YoNGE, C.M. 1949. On the structure and adaptations of the Tellinacea, deposit-feeding Eulamellibranchia. Philosophical Transactions of the Royal Society of London Series B, Biological Sciences 234 (609): 29-76.

YongE, C.M. 1957. Mantle fusion in the Lamellibranchia. Pubblicazione della Stazione Zoologica di Napoli 29: 151-171.

Zwarts, L.; A.M. Blomert; P. SpaAk \& B. VRies. 1994. Feeding radius, burying depth and siphon size of Macoma balthica and Scrobicularia plana. Journal of Experimental Marine Biology and Ecology 183: 193-212.

Submitted: 24.XI.2011; Accepted: 14.V.2012. Editorial responsibility: Carolina Arruda Freire 